CZU: 634.2.577.4(478.9)

https://doi.org/10.53082/1857-3142.21.85.01

\section{Cercetări privind îmbunăătăirea sortimentului de cais}

Maria PÎNTEA, doctor habilitat în ştiinţe biologice, https://orcid.org/0000-0002-5589-4158

Institutul Ştiințifico-Practic de Horticultură şi Tehnologii Alimentare

Rezumat. În articol sunt prezentate unele rezultate privind manifestarea particularităților specifice ale sortimentului de cais local și cel introdus în ultimul timp în condițiile pedoclimatice ale Republicii Moldova. Cele mai favorabile caracteristici țin de adaptabilitate, unități „chilling units” înalte, autocompatibilitate, productivitate sustenabilă și calități înalte ale fructelor.

Cuvinte-cheie: cais, soiuri, adaptabilitate, productivitate, Republica Moldova.

Summary. In the article there are presented some results of manifestation of specific pecuilirities of local and introduced in the last time apricot assortment within conditions of the Republic of Moldova. Main favourable characteristic there are adaptability, high chilling units, autocompatibility, sustainable productivity and fruit qualities.

Keywords: apricot, varieties, adaptability, productivity, Republic of Moldova.

\section{INTRODUCERE}

Caisul este fructul preferat al moldovenilor din moşi-strămoşi. Fructificarea sustenabilă a acestei specii este posibilă numai în condiţii specifice, mai ales cele microclimatice vizând evitarea riscurilor ce ţin de asigurarea dezvoltării optimale a mugurilor de rod şi a florilor, fără pierderea lor în „ferestrele de friguri brusce de iarnă şi primăvară" etc. Declinul relativ rapid al majorităţii plantaţiilor de cais din republică impune eforturi mari în vederea redresării culturii lui, creării de noi soiuri, precum şi introducerii sortimentului modernizat, aceasta fiind o sarcină importantă. Astfel, genotipurile noi trebuie să demonstreze caracteristici biologice şi de producţie valoroase în condiţiile reliefului foarte diversificat al Republicii Moldova, adică ale resurselor agroclimatice foarte diverse. Sortimentul actualmente înregistrat în Republica Moldova necesită a fi completat cu soiuri ce posedă adaptabilitate şi plasticitate ecologică cât mai bune la condiţiile locale de mediu. Piaţa fructelor de cais cere soiuri cu maturare extratimpurie/ timpurie/tardivă/extratardivă a fructelor, calităţi performante ale fructelor (tot mai insistent se cere omo- genitatea fructelor şi uniformitatea colorării intense a lor, masa mare, pulpa fermă cu detaşare uscată de la sâmburele relativ mic, aspect exterior atractiv, compoziţie biochimică nutritiţională foarte valoroasă etc.) şi desigur rezistenţă/toleranţă la bolile principale, cum ar fi Sharka şi cancerul bacterian [2-6]. Perioada de cercetare-generalizare: anii 1995-2019; sursa de finanțare: proiectele instituționale din pomicultură (din cadrul ICP și IȘPHTA).

\section{MATERIALE ȘI METODE DE CERCETARE}

Cercetările experimentale au fost efectuate în colecţiile naţionale de cais (Staţiunea Experimentală „Codrul”, Institutul Ştiinţifico-Practic de Horticultură şi Tehnologii Alimentare). În calitate de material biologic pentru cercetare s-au utilizat soiuri şi selecţii introduse din selecţia mondială (preponderent din România, Ucraina, SUA, Canada, Uzbekistan, Franţa), care, conform cercetărilor preliminare, s-au arătat a fi de perspectivă pentru Republica Moldova. Ca portaltoi a fost folosit biotipul de zarzăr MVA, schemele de plantare - 6 × 4 m şi $5 \times 4$ m, în lipsa irigării. Studiul însuşirilor biologice şi de producţie a fost efectuat în baza observărilor, determinărilor şi analizelor cu privire la: fenologia şi rezistenţa la factorii nefavorabili biotici şi abiotici a organelor generative, producţia de fructe pe pom, calităţile organoleptice şi biochimice ale fructelor, rezistenţa la boli şi la factorii abiotici în comparație cu sortimentul omologat pentru Republica Moldova. Pentru desfășurarea cercetărilor s-au aplicat principiile metodologice şi metodele aprobate în ameliorarea genetică şi studiul speciilor pomicole [3-5].

\section{REZULTATE ȘI DISCUȚII}

Etapele de bază ale cercetărilor experimentale privind ameliorarea sortimentului de cais pentru condiţiile şi necesităţile de bază din ţara noastră cuprind mai multe perioade distincte, primele dintre ele (anii 1957-1985) fiind indisolubil legate de utilizarea preponderentă a caiselor la diferite tipuri de procesare. Diversificarea şi sporirea an de an a bazei genetice de studiu şi selecţia elitelor, obţinute prin experimentarea diferitor combinaţii de hibridare dintre soiurile locale şi cele introduse, au permis alegerea celor de perspectivă, în special a celor ce posedă caractere şi însuşiri noi corespunzătoare scopurilor propuse la organizarea culturilor comparative de concurs, testarea şi implementarea în producerea industrială a caiselor. Astfel, sortimentul înregistrat a trecut prin mai multe transformări: până în 1990 - numai 4 soiuri, dintre care 3 create în Moldova. După 1990 (anii 1991-2002) s-au înregistrat 9 soiuri, dintre care 7 create în Republica Moldova. Actualmente, Catalogul de Stat al Soiurilor de Plante al Republicii Moldova [1] conţine 20 de soiuri 
de cais, dintre care 9 create în Republica Moldova (IŞPHTA). Începând cu ultima perioadă, sunt considerate ca prioritare soiurile destinate consumului proaspăt, cu pulpa fermă, pretabile la păstrare temporară, transportare la distanţe lungi etc. De notat că printre cele peste cincizeci de soiuri şi selecţii noi înscrise în anii 1995-2019 pentru testarea de stat în vederea înregistrării pentru multiplicare în Republica Moldova predominante sunt soiurile create în cadrul IŞPHTA pentru condiţiile locale.

Soiurile introduse CR 263, Şalah, Umberto, Orange red, Kyoto, Dacia etc., de rând cu cel mai bine adaptat şi răspândit în condiţiile locale Krasnoşcioki, completează bine golurile temporare de fructe din perioada timpurie spre medie, medie-tardivă. Conform datelor prezentate în tabelul 1 , care reprezintă o serie de soiuri şi elite create în Republica Moldova, se evidenţiază încadrarea lor în grupul celor de vigoare medie, iar producţia kg/pom este relativ înaltă: la majoritatea soiurilor - peste $20 \mathrm{~kg} /$ pom. Nota de degustare a fructelor proaspete fiind mai înaltă decât la martor (peste 4,5 p.). De notat că investigaţiile respective au fost efectuate în lipsa irigării, ceea ce demonstrează o dată în plus gradul lor înalt de adaptabilitate la condiţiile locale de cultură.

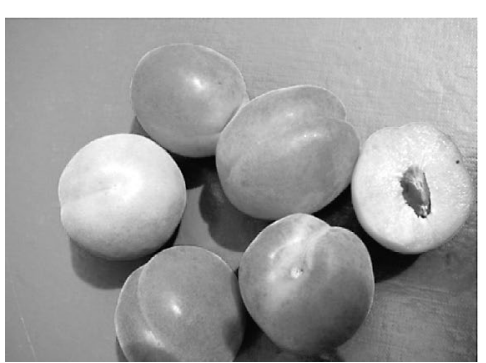

A

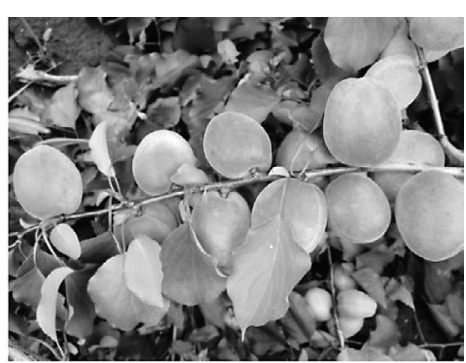

B

Figura 1. A - soiul Orange red; B - soiul Vasile Cociu

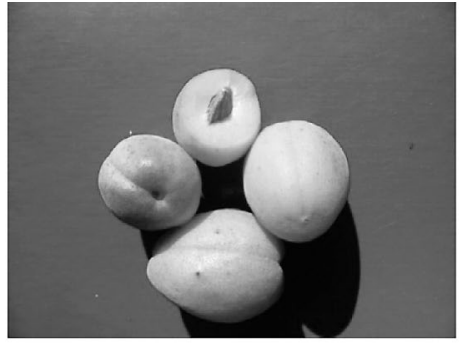

A

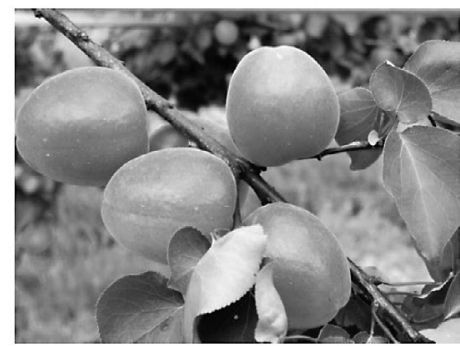

B
Figura 2. A - soiul Olimp; B - soiul Magic cot

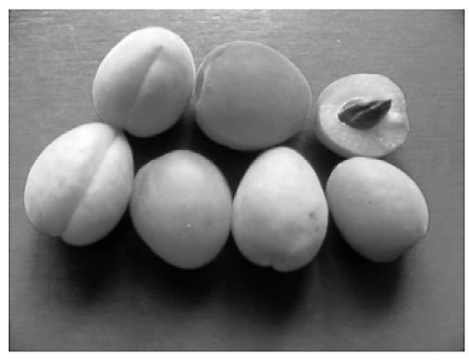

A

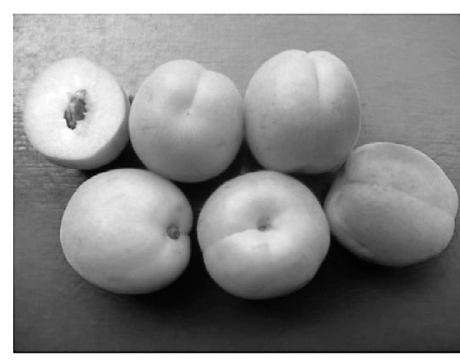

B
Figura 3. A- soiul Faralia; B - soiul Kyoto

Tabelul 1

\section{Caracteristicile biochimice și organoleptice ale unor soiuri introduse și hibrizi autohtoni de cais, anul 2019 (unele comparații cu anul 2018)}

\begin{tabular}{|l|c|c|c|c|c|c|c|c|c|}
\hline $\begin{array}{c}\text { Genotipul/an de } \\
\text { studiu }\end{array}$ & $\begin{array}{c}\text { Nota de } \\
\text { degus- } \\
\text { tare (1-5 } \\
\text { p.) }\end{array}$ & $\begin{array}{c}\text { Subst. } \\
\text { uscată, } \\
\%\end{array}$ & $\begin{array}{c}\text { Zahăr } \\
\text { total,\% }\end{array}$ & $\begin{array}{c}\text { Zahăr } \\
\text { reducti- } \\
\text { bil, \% }\end{array}$ & $\begin{array}{c}\text { Za- } \\
\text { haro- } \\
\text { ză, \% }\end{array}$ & $\begin{array}{c}\text { Acizi } \\
\text { titrabili, } \\
\%\end{array}$ & $\begin{array}{c}\text { Subst. co- } \\
\text { lorante şi } \\
\text { tanante, } \\
\text { mg/\% }\end{array}$ & $\begin{array}{c}\text { Vitamina } \\
\mathbf{C}, \mathbf{m g} \%\end{array}$ & $\begin{array}{c}\text { Indicele } \\
\text { zahărl } \\
\text { acid. }\end{array}$ \\
\hline Paterson & 4,6 & 15,18 & 8,10 & 4,42 & 5,06 & 1,82 & 83,14 & 12,10 & 4,45 \\
\hline 1P 7/2019 & 4,5 & 16,67 & 5,60 & 3,60 & 2,00 & 2,87 & 62,36 & 16,62 & 1,95 \\
\hline 1P7/2018 & 4,5 & 17,83 & 5,70 & 4,70 & 0,84 & 2,97 & 20,78 & 12,76 & 1,90 \\
\hline Farbaly/2019 & 4,5 & 15,60 & 8,10 & 4,05 & 4,05 & 2,00 & 83,10 & 9,68 & 2,02 \\
\hline Farbaly/2018 & 4,5 & 15,87 & 5,54 & 1,45 & 4,09 & 1,40 & 20,78 & 30,80 & 3,95 \\
\hline Faralia/2019 & 4,55 & 16,70 & 5,56 & 4,27 & 1,29 & 0,77 & 41,57 & 11,88 & 3,97 \\
\hline Faralia/2018 & 4,55 & 12,07 & 3,76 & 1,23 & 2,53 & 3,53 & 83,14 & 14,52 & 1,00 \\
\hline F2X & 4,4 & 16,50 & 8,10 & 4,42 & 3,68 & 1,82 & 83,14 & 9,68 & 4,45 \\
\hline F1X & 4,55 & 15,90 & 6,66 & 2,40 & 4,26 & 2,05 & 83,14 & 14,96 & 3,25 \\
\hline 1P14/2019 & 4,45 & 16,67 & 5,72 & 3,02 & 2,70 & 2,75 & 62,36 & 15,84 & 2,08 \\
\hline 1P14/2018 & 4,6 & 10,00 & 2,56 & 3,76 & 0,96 & 2,86 & 83,14 & 14,52 & 0,89 \\
\hline 1P10 & 4,47 & 16,0 & 4,83 & 3,20 & 1,63 & 2,07 & 49,88 & 9,72 & 2,33 \\
\hline Farglo & 4,5 & 16,90 & 7,02 & 4,60 & 2,42 & 0,96 & 62,36 & 8,80 & 7,31 \\
\hline
\end{tabular}




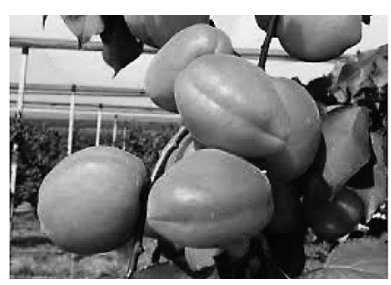

A

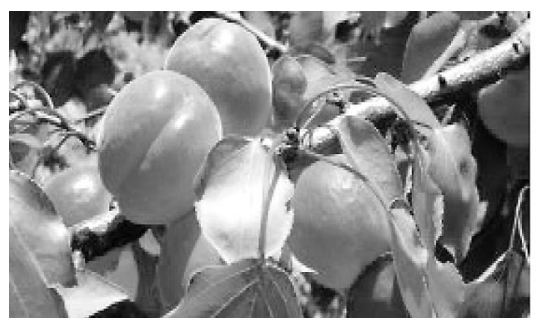

A
Figura 4. A - Farbaly; B - Pincot

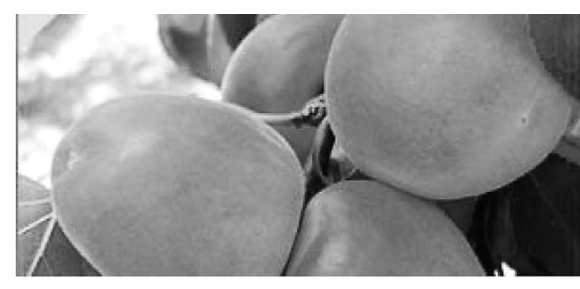

B

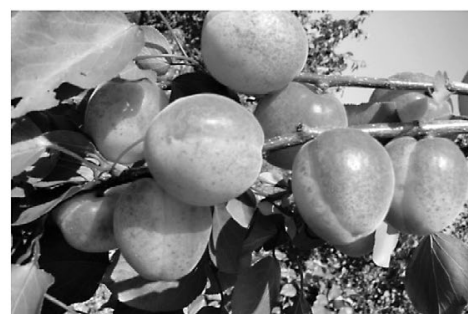

B
Figura 5. A - Big red; B - Krasnoșcioki

Compararea testelor biochimice efectuate pentru fructele soiurilor introduse Farbaly, Faralia, precum şi a două elite evidenţiate (1P7 şi 1P14) au demonstrat influenţa condiţilor microclimatice asupra rezultatelor obţinute (tab. 2). Spre exemplu, în a. 2018 conţinutul de substanţe tanante şi colorante, precum şi al vitaminei C au fost mai înalte la Faralia 83,14 mg/\%. Un conţinut înalt de substanţă uscată s-a remarcat la hibridul 1P7-17,83\% (a. 2018) şi 16,67\% (a. 2019), fiind urmat de soiul Farbaly $-16,87 \%$, tot el a avut peste $30 \%$ de vit. C (a. 2018) (tab. 2). Soiul american Paterson, care posedă şi în condiţiile Republicii Moldova adaptabilitate bună şi plasticitate ecologică înaltă, s-a evidenţiat printr-un conţinut înalt de substanţe tanante şi colorante $(83,14 \mathrm{mg} / \%)$, precum şi de substanţe uscate $(15,18 \%)$. Din păcate, acest soi este sensibil la Sharka în condiţiile locale.

Datele obţinute ne demonstrează relevant că în condiţiile de cultivare ale ţării noastre genotipurile evidenţiate introduse, care posedă un complex de caracteristici favorabile pentru promovare (cum ar fi: productivitate stabilă, rezistenţă sporită la factorii nefavorabili biotici şi abiotici, vigoare medie de creştere, capacitatea de a forma mai multe tipuri de formaţiuni de rod etc.), merită a fi utilizate şi în programele ulterioare de ameliorare genetică a speciei de cais (Prunus armeniaca L.).

De notat că majoritatea soiurilor introduse cercetate se încadrează în grupul celor de vigoare medie. Astfel, datele cele mai indicate de promovare/îmbunătăţire a sortimentului de cais rămân a fi uniformitatea maturării fructelor, grosimea şi rezistenţa pieliţei, fermitatea pulpei, suculenţa, aroma, neaderenţa la pulpă şi mărimea sâmburelui, data recoltării, stabilitatea producţiei pe pom, găsirea/selectarea corectă a sectoarelor cu resur- se agroclimatice potrivite cultivării eficiente a caisului.

Cercetările efectuate asupra caracteristicilor de bază biologice şi de producţie ale genofondului de perspectivă sus-numit vizând scopul general de a stabili potenţialul de plasticitate ecologică şi adaptibilitate bună la condiţiile locale şi obţinere de fructe cu calităţi moderne au permis de a evidenţia un şir de soiuri, reprezentabili ca donatori de anumite caracteristici preţioase (tab. 1, fig. 1-5). Actualmente în producere sunt răspândite în special soiurile Nadejda, Codrean (maturare medietimpurie a fructelor, destinate pieţei locale), Vasile Cociu (maturare timpurie spre medie, fructe cu calităţi comerciale înalte, intensiv colorate, pulpa fermă, păstrare bună la frigider, export), Nadejda (maturare medie, fructe cu calităţi comerciale înalte, pulpa fermă, păstrare bună în stare proaspătă la frigider, pretabile pentru export), Kostiujenski (bun polenizator pentru majoritatea soiurilor înregistrate în ţară, maturare medietardivă, calităţi excelente la consumul proaspăt, dar în special la procesare). Soiurile noi introduse, evidenţiate prin studii comparative (Orange red, Olimp, Magic cot, Pincot, Farbaly etc.) sunt bine-venite la completarea golurilor de fructe de cais din perioada medie-tardivă, fiind înalt productive, fructe calitative atât pentru consum proaspăt, cât şi pentru procesare industrială. Elitele evidenţiate (3-2-17A, 1P14, 1P7, 1P10) sunt bine-venite la completarea golurilor de fructe de cais din perioada medie-tardivă, fiind înalt productive, fructe calitative atât pentru consum proaspăt, cât şi pentru procesare industrială. Aceste genotipuri pot fi utilizate atât pentru producerea fructelor în anumite scopuri, cât şi pentru utilizare în programele ulterioare de ameliorare genetică şi de creare de noi soiuri de cais pentru condiţiile Republicii Moldova.

\section{CONCLUZII}

Sortimentul de cais actualmente înregistrat pentru înmulţire în Republica Moldova este constituit în egală măsură din soiuri autohtone şi introduse din cadrul european, care se caracterizează prin adaptabilitate înaltă şi plasticitate ecologică largă la condiţiile agroclimatice variabile din Republica Moldova. Îmbunătăţirea continuă a sortimentului caisului se bazează pe: lărgirea perioadei de maturare a fructelor (extratimpurie - prima decadă a lunii iunie, tardivă - a doua decadă a lunii august); fructe atractiv colorate, cu pulpa fermă la maturarea de recoltare şi capacitate bună de păstrare timp de câteva săptămâni; maturare timpurie spre medie, cu fructe 


\section{Caracteristicile generale ale unor soiuri noi de cais}

\begin{tabular}{|c|c|c|c|c|c|c|}
\hline Soiul & $\begin{array}{l}\text { Mărimea } \\
\text { fructelor }\end{array}$ & $\begin{array}{l}\text { Pro- } \\
\text { ductivi- } \\
\text { tatea }\end{array}$ & $\begin{array}{l}\text { Calitatea } \\
\text { genera- } \\
\text { lă a } \\
\text { fructelor }\end{array}$ & $\begin{array}{l}\text { Destina- } \\
\text { tia } \\
\text { fructelor }\end{array}$ & $\begin{array}{l}\text { Particularităţi } \\
\text { specifice }\end{array}$ & $\begin{array}{c}\text { Caracteristici importante de } \\
\text { adaptabilitate }\end{array}$ \\
\hline \multicolumn{7}{|c|}{ Soiuri introduse } \\
\hline NJA-42 &,+++ & +++ & ++ & CP, PR & $\begin{array}{l}\text { Pulpa parţial ade- } \\
\text { rentă la sâmbure }\end{array}$ & $\begin{array}{l}\text { Productivitate stabilă, calita- } \\
\text { tea fructelor. } \\
\text { Rezistenţă bună la factorii } \\
\text { nefavorabili abiotici locali }\end{array}$ \\
\hline $\begin{array}{l}\text { Orange red } \\
\text { (NJA-32) }\end{array}$ &,++++++ & +++ & +++ & PR, CP & $\begin{array}{l}\text { Autoincompatibili- } \\
\text { tate pronunţată }\end{array}$ & $\begin{array}{l}\text { Timpurietatea maturării, calita- } \\
\text { tea fructelor. Gust echilibrat }\end{array}$ \\
\hline Kyoto &,+++++ & +++ &,+++++ & $\mathrm{CP}, \mathrm{PR}$ & $\begin{array}{l}\text { Autofertilitate pro- } \\
\text { nunţată }\end{array}$ & $\begin{array}{l}\text { Timpurietatea maturării şi } \\
\text { calitatea înaltă a fructelor }\end{array}$ \\
\hline Big red &,+++++ & +++ &,+++++ & $\mathrm{CP}, \mathrm{PR}$ & $\begin{array}{l}\text { Autoincompatibili- } \\
\text { tate pronunţată }\end{array}$ & $\begin{array}{l}\text { Productivitate, calitatea fruc- } \\
\text { telor }\end{array}$ \\
\hline Bergeron & ++ & +++ &,++++++ & $\mathrm{CP}, \mathrm{PR}$ & $\begin{array}{l}\text { Autofertilitate pro- } \\
\text { nunţată }\end{array}$ & $\begin{array}{l}\text { Productivitate, calitatea fruc- } \\
\text { telor }\end{array}$ \\
\hline Tyrinthos & +++ & +++ & ++ & $\mathrm{CP}$ & $\begin{array}{l}\text { Autofertilitate pro- } \\
\text { nunţată }\end{array}$ & $\begin{array}{l}\text { Timpurietatea maturării, calita- } \\
\text { tea fructelor }\end{array}$ \\
\hline Faralia & +++ & +++ & +++ & $\mathrm{CP}$ & $\begin{array}{l}\text { Autofertilitate, fer- } \\
\text { mitatea pulpei }\end{array}$ & $\begin{array}{l}\text { Timpurietatea maturării, calita- } \\
\text { tea fructelor }\end{array}$ \\
\hline Farbaly & +++ & +++ & +++ & $\mathrm{CP}, \mathrm{PR}$ & $\begin{array}{l}\text { Autofertilitate pro- } \\
\text { nunţată }\end{array}$ & $\begin{array}{l}\text { Productivitate, calitatea fruc- } \\
\text { telor }\end{array}$ \\
\hline \multicolumn{7}{|c|}{ Soiuri create în Republica Moldova } \\
\hline Bucuria &,+++ & +++ & +++ & CP & $\begin{array}{l}\text { Autofertilitate. } \\
\text { Fructe moi, gal- } \\
\text { bene, aderente la } \\
\text { sâmbure }\end{array}$ & $\begin{array}{l}\text { Productivitate, calitatea bună } \\
\text { a fructelor. Rezistenţă bună } \\
\text { la factorii nefavorabili abiotici } \\
\text { locali }\end{array}$ \\
\hline Nadejda & +++ & $\begin{array}{l}++ \\
+++\end{array}$ & ++ & $\mathrm{CP}, \mathrm{PR}$ & $\begin{array}{l}\text { Mugurii de rod de } \\
\text { rezistenţă medie } \\
\text { la ger }\end{array}$ & $\begin{array}{l}\text { Productivitate, calitatea fruc- } \\
\text { telor. } \\
\text { Rezistenţă bună la factorii } \\
\text { nefavorabili abiotici locali }\end{array}$ \\
\hline Vasile Cociu & +++ & +++ & +++ & CP, PR & $\begin{array}{l}\text { Înflorire tardivă. } \\
\text { Aspect foarte atră- } \\
\text { gător (70-80\% de } \\
\text { roşu al fructelor) }\end{array}$ & $\begin{array}{l}\text { Productivitate, calitatea foarte } \\
\text { bună a fructelor la procesare. } \\
\text { Rezistență la factorii nefavo- } \\
\text { rabili abiotici locali. Înflorire } \\
\text { tardivă }\end{array}$ \\
\hline Codrean & ++ & +++ & +++ & $\mathrm{CP}, \mathrm{PR}$ & $\begin{array}{l}\text { Autofertilitate pro- } \\
\text { nunţată, culoare } \\
\text { uniformă galbe- } \\
\text { nă a pieliţei şi a } \\
\text { pulpei }\end{array}$ & $\begin{array}{l}\text { Productivitate bună, calitatea } \\
\text { fructelor, transportabilitate ex- } \\
\text { celentă a fructelor. Rezistenţă } \\
\text { la factorii nefavorabili abiotici } \\
\text { locali }\end{array}$ \\
\hline Kostiujenski & ++ & +++ & +++ & $\mathrm{CP}, \mathrm{PR}$ & $\begin{array}{l}\text { Autofertilitate pro- } \\
\text { nunţată. Culoarea } \\
\text { galbenă a pulpei, } \\
\text { suculenţă înaltă }\end{array}$ & $\begin{array}{l}\text { Productivitate, calitatea foarte } \\
\text { bună a fructelor la procesare. } \\
\text { Rezistenţă bună la factorii } \\
\text { nefavorabili abiotici locali }\end{array}$ \\
\hline Raduga & ++ & +++ &,$++ \quad+++$ & CP, PR & $\begin{array}{l}\text { Autofertilitate slab } \\
\text { pronunţată. } \\
\text { Pulpa crocantă }\end{array}$ & $\begin{array}{l}\text { Productivitate, calitatea fruc- } \\
\text { telor la procesare. Rezistenţă } \\
\text { bună la factorii nefavorabili } \\
\text { abiotici locali }\end{array}$ \\
\hline
\end{tabular}

Legendă: +++ mare, ++ medie, + mică, slabă, joasă. CP - consum proaspăt, PR - procesare. 
mari şi foarte mari, atractiv colorate, cu pulpa fermă, capabile de a fi transportate la distanţe lungi. Este indispensabil de a accentua că genotipurile nou-create sau introduse din alte regiuni de cultură trebuie să aibă rezistenţă complexă la factorii nefavorabili biotici şi abiotici, precum şi productivitate stabil înaltă de fructe în condițiile de schimbări climatice accentuate.

Notă: Cercetările au fost efectuate în cadrul proiectului „Program de Stat” 20.80009.5107.14 „Utilizarea metodelor genetice și biotehnologiilor moderne în scopul creării, devirozării și implementării în producere a soiurilor culturilor pomicole, portaltoaielor".

\section{BIBLIOGRAFIE}

1. Catalogul soiurilor de plante al Republicii Moldova pentru anul 2019, Chişinău, 2019, p. 64-65.

2. Cociu V., Oprea Şt. Metodele de cercetare în ameliorarea plantelor pomicole. Cluj-Napoca, Editura Dacia, 1989, $123 \mathrm{p}$.

3. Isakova M.D., Smîkov V.K. Selekţia abrikosa v SSR Moldova. În: Sortoizucenie i selekţia plodovîh kultur. Chișinău, Editura Știința, 1991, p. 37-53.

4. Pîntea M. Sortimentul de cais omologat şi de perspectivă. În: Cercetări în Pomicultură. Vol. I (Institutul de Cercetări pentru Pomicultură). Chişinău, Editura AŞM, 2002, p. 59-65.

5. Pîntea M. Cultivarea caisului. Chişinău, „Tipografia Centrală", 2003, 56 p.

6. Souty M., Audergon J.M., Chambroy L. Apricot, le critere de qualite. In: L'arboriculture fruitiere, Nr. 91, 1990, p. 16-24.

RECENZIE ŞTIINȚIFICĂ - Ilie DONICA, doctor habilitat în știinte agricole, profesor cercetător.

Materialul a fost prezentat la 01.06.2021. 